\title{
Eocene high grade metamorphism and crustal anatexis in the North Himalaya Gneiss Domes, Southern Tibet
}

\author{
GAO LiE ${ }^{1 *}$, ZENG LingSen ${ }^{1} \&$ XIE KeJia ${ }^{2}$ \\ ${ }^{1}$ Institute of Geology, Chinese Academy of Geological Sciences, Beijing 100037, China; \\ ${ }^{2}$ Non-Ferrous Mineral Exploration Engineering Research Center of Henan Province, Zhengzhou 450016, China
}

Received July 6, 2011; accepted September 1, 2011; published online November 19, 2011

\begin{abstract}
Determination of the timing and geochemical nature of early metamorphic and anatectic events in the Himalayan orogen may provide key insights into the physical and chemical behavior of lower crustal materials during the early stage of tectonic evolution in large-scale collisional belts. The Yardoi gneiss dome is the easternmost dome of the North Himalayan Gneiss Domes (NHGD), and contains three types of amphibolites with distinct mineral assemblage, elemental and radiogenic isotope geochemistry, as well as various types of gneisses. SHRIMP zircon $\mathrm{U} / \mathrm{Pb}$ analyses on the garnet amphibolite and garnet-bearing biotite granitic gneiss

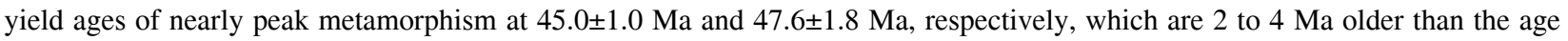
for partial melting in migmatitic garnet amphibolite $(43.5 \pm 1.3 \mathrm{Ma})$. Available data have demonstrated that ultra-high pressure metamorphism in the Tethyan Himalaya occurred at $\sim 55 \mathrm{Ma}$, and high amphibolite facies to granulite facies metamorphism at 45 to $47 \mathrm{Ma}$. In addition, partial melting at thickened crustal conditions occurred at $43.5 \pm 1.3 \mathrm{Ma}$, which led to the formation of high $\mathrm{Sr} / \mathrm{Y}$ ratios two-mica granites. The high-grade metamorphic rocks in the NHGD may represent the subducted front of the Indian continental lithosphere. In large collisional belts, fertile components in crustal materials could melt and form granitic melts with relatively high $\mathrm{Na} / \mathrm{K}$ and $\mathrm{Sr} / \mathrm{Y}$ ratios under thickened crustal conditions, significantly different from those formed by decompressional melting during rapid exhumation.
\end{abstract}

Tibet, Himalayan orogenic belt, North Himalayan Gneiss Domes, high-grade metamorphism, crustal anatexis

Citation: Gao L E, Zeng L S, Xie K J. Eocene high grade metamorphism and crustal anatexis in the North Himalaya Gneiss Domes, Southern Tibet. Chin Sci Bull, 2012, 57: 639-650, doi: 10.1007/s11434-011-4805-4

The Himalayan orogenic belt is the type example of collisional belts worldwide, and has been considered to have resulted from the continental collision between India and Eurasia [1-5]. However, the timing of the onset of this collision has been hotly debated. For the past 30 years, a number of studies have been directed to constrain the timing of the collision. Studies on collisional time vary widely, in-

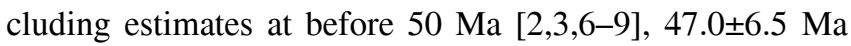
[10], or $35 \mathrm{Ma}$ [11]. Determination of the timing and geochemical nature of metamorphic and anatectic events in the Himalayan orogen could provide key information with regard to: (1) constraint on timing of the India-Eurasia continental collision; (2) understanding relationships among meta-

\footnotetext{
*Corresponding author (email: liegao09@gmail.com)
}

morphism, crustal partial melting and tectonic deformation; and (3) drawing broader implications for the timing and dynamics of tectonic transitions along the Himalayan orogen.

During the evolution of the Himalayan orogen, middle to lower crustal materials have experienced various types of metamorphic and partial melting reactions in response to the tectonic transition (e.g. from early N-S compression, concurrent N-S compression and extension, to latest E-W extension) [12-20]. Such reactions have resulted in the formation of various types of high-grade metamorphic rocks, granites and migmatites. These crystalline rocks are distributed along two sub-parallel belts, the High Himalayan Crystalline Sequence (HHCS) to the south, and the North Himalayan Gneiss Domes (NHGD) to the north. They therefore have preserved records of the nature of high-grade 
metamorphism, crustal anatexis, deformation and near-surface processes associated with the active Indian-Eurasian continental collision, and are an excellent natural field laboratory to study the tectonic evolution of collisional orogens. In addition, these rocks provide an opportunity to document the physical and chemical behavior of lower crustal materials in large-scale collisional belts. A great number of studies have demonstrated that (1) the Tethyan Himalaya experienced eclogite facies metamorphism at about $55 \mathrm{Ma}$ (Lu-Hf and Sm-Nd isochron age) [21] and amphibolite facies metamorphism at $47 \mathrm{Ma}$ (Sm-Nd isochron age) [21]. In contrast, UHP eclogite facies metamorphism within the High Himalaya occurred at $\sim 46 \mathrm{Ma}$ (zircon U/Pb age) [22,23]; (2) granites generally are the products of crustal anatexis and formed along the NHGD over a time span of $\sim 44$ to $10 \mathrm{Ma}[13,16,17,24-26]$, and along the HHCS from $\sim 37$ to $10 \mathrm{Ma}[15,27-29]$; (3) the two-mica granites and leucogranites older than $30 \mathrm{Ma}$ were derived from partial melting of a source mixed of garnet amphibolite with subordinate pelitic gneiss [16-20]; and (4) though the formation mechanisms of the Miocene granites are uncertain [27,29-31], most available data have indicated that these younger leucogranites ( $<27 \mathrm{Ma}$ ) resulted from partial melting of the metapelite of the HHCS during rapid exhumation [25-28,32-37].

Few studies have documented metamorphism and partial melting events of Pre- or Eocene age within the Chinese part of the Himalaya orogen. Recent detailed investigations on the Yardoi Gneiss Dome (YGD), the easternmost member of the NHGD (Figure 1(a)), have indicated that the twomica granites in this dome and adjacent areas formed at 43-44 Ma [17], and are characterized by relatively high
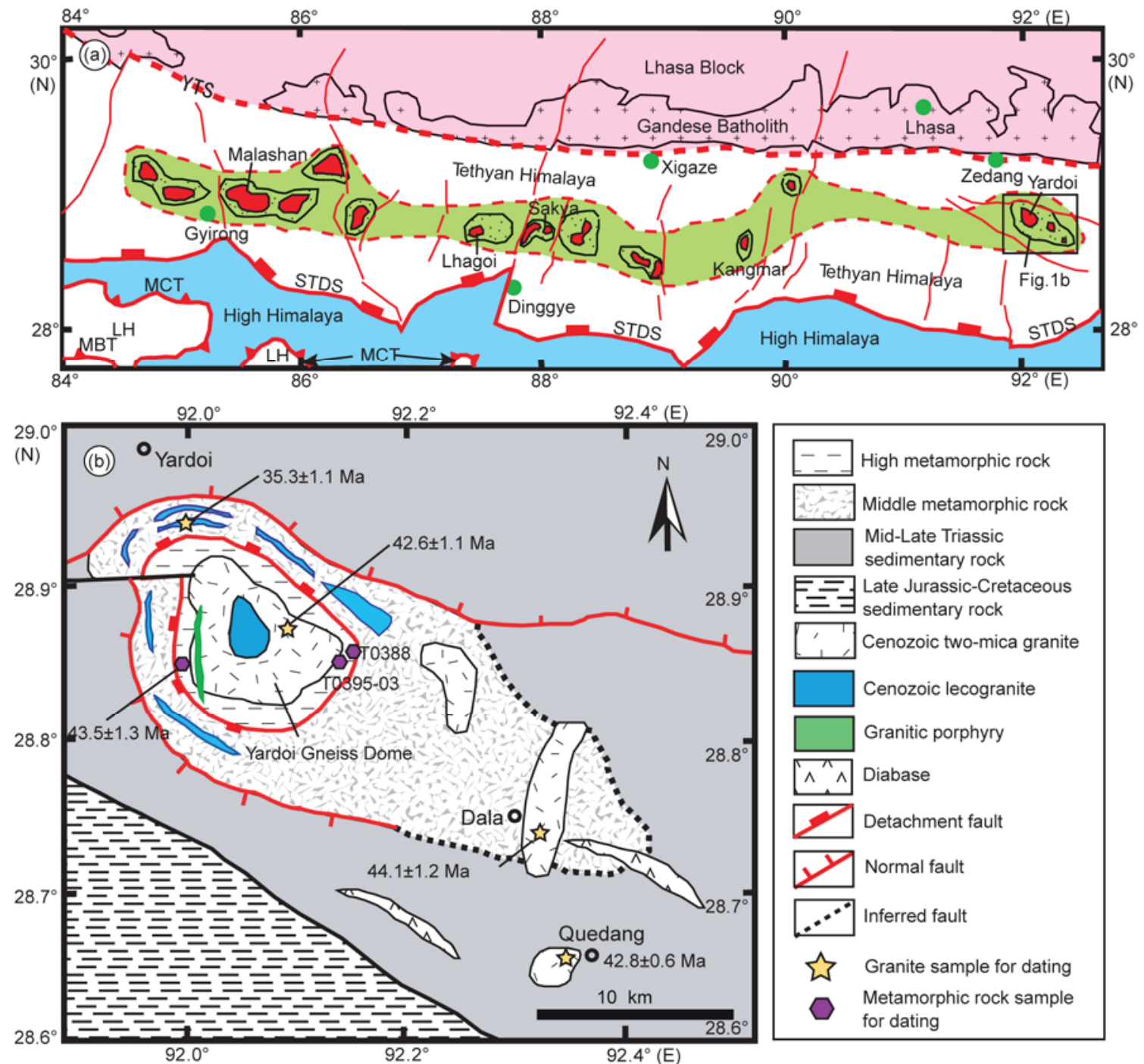

Figure 1 (a) Simplified geologic map of the Himalayan orogenic belt, southern Tibet (after Zeng et al. [16]); (b) simplified geologic map of the Yardoi area showing the Yardoi gneiss dome (YGD), the Dala and Quedang plutons, as well as the locations of sample T0388 and T0395-03 for zircon SHRIMP $\mathrm{U} / \mathrm{Pb}$ dating. Age source data are from [13,16,17]. YTS,Yarlung-Tsangpo suture; STDS, southern Tibet Detachment System; MCT, Main Central Thrust; MBT, Main Boundary Thrust; LH, Lower Himalayan Crystalline Sequence. 
$\mathrm{Sr} / \mathrm{Y}$ and low $\mathrm{Rb} / \mathrm{Sr}$ ratios. Moreover, leucogranite dikes formed at $35.3 \mathrm{Ma}$ and have relatively elevated $\mathrm{Rb} / \mathrm{Sr}$ ratios [16]. Furthermore, both suites of granites have relatively lower ${ }^{87} \mathrm{Sr} /{ }^{86} \mathrm{Sr}$ ratios, consistent with a derivation from partial melting of crustal material dominated by amphibolite. These anatectic events in the Yardoi area are clearly earlier than those in other NHGD and HHCS, and have been derived from a different mechanism. As compared with partial melting of muscovite, amphibolite melting requires a much higher temperature and pressure, and should have formed closer to lower crustal P and T conditions during the early stage of a collisional orogen. Thus, documenting the timing of metamorphism and amphibolite melting could provide important data to constrain the timing of the India-Eurasia continental collision.

In this contribution, we present SHRIMP zircon $\mathrm{U} / \mathrm{Pb}$ age data from garnet amphibolites, as well as from garnetbearing granitic gneisses, to constrain the timing of high grade metamorphism associated with the early stage of the India-Eurasia continental collision. These data, combined with literature information related to metamorphism and anatectic events from southern Tibet, are used to evaluate large-scale tectonic implications for the Himalayan orogen.

\section{Geological setting}

Between the Main Central Thrust (MCT) and the YarlungTsangpo Suture (YTS), there are two sub-parallel belts, the High Himalayan Crystalline Series (HHCS) and the North Himalayan Gneiss Domes (NHGD) (Figure 1(a)). These belts are separated by the STDS. Previous studies on the granites occurring along both belts have revealed significant alongstrike differences in the style of emplacement, geochemistry, timing and mechanism of formation [16-19,24,29-32,36, 38-46]. Although each gneiss dome of the NHGD shows subtle differences in detail, they share similar characteristics overall. For each of them, the core consists of high-grade metamorphic rocks and Cenozoic granites, and the margin constitutes low grade metamorphic or unmetamorphosed sedimentary rocks. Core and margin areas are separated by ductile detachment faults. With the exception that granites in the core of some domes (e.g. Kangma) formed during the early Paleozoic (566 to $507 \mathrm{Ma}$ ) [40,47-49], most of them are of Cenozoic (44 to $10 \mathrm{Ma}$ ) [13,16,17,24,29,40,45,46,50].

The YGD is located at the easternmost end of the NHGD (Figure 1(b)). From core to margin, it consists of semicircular Cenozoic granites and high-grade metamorphic rocks, extending outward to medium- to low-grade metamorphic rocks, and finally is separated from Tethyan sedimentary rocks of Triassic to Cretaceous age by a detachment fault (Figure 1(b)) [51]. High-grade metamorphic rocks include augen gneiss, garnet biotite gneiss, garnet-bearing metapelite, amphibolite, and garnet amphibolite with subordinated epidotite and pyroxenite. Medium- to low-grade rocks consist of garnet-bearing mica schist and garnet graphite schist. Amphibolites include amphibolites without garnet, garnet amphibolites and migmatitic garnet amphibolites. Amphibolites without any garnet occur as small lenses within intensively deformed garnet graphite schists (Figure 2(a)); whereas, garnet amphibolites are present as relatively thick layers sub-parallel to the foliation of the granitic gneiss, metapelite or marble (Figure 2(b)). Augen gneisses and garnet biotite gneisses are more abundant and widely distributed (Figure
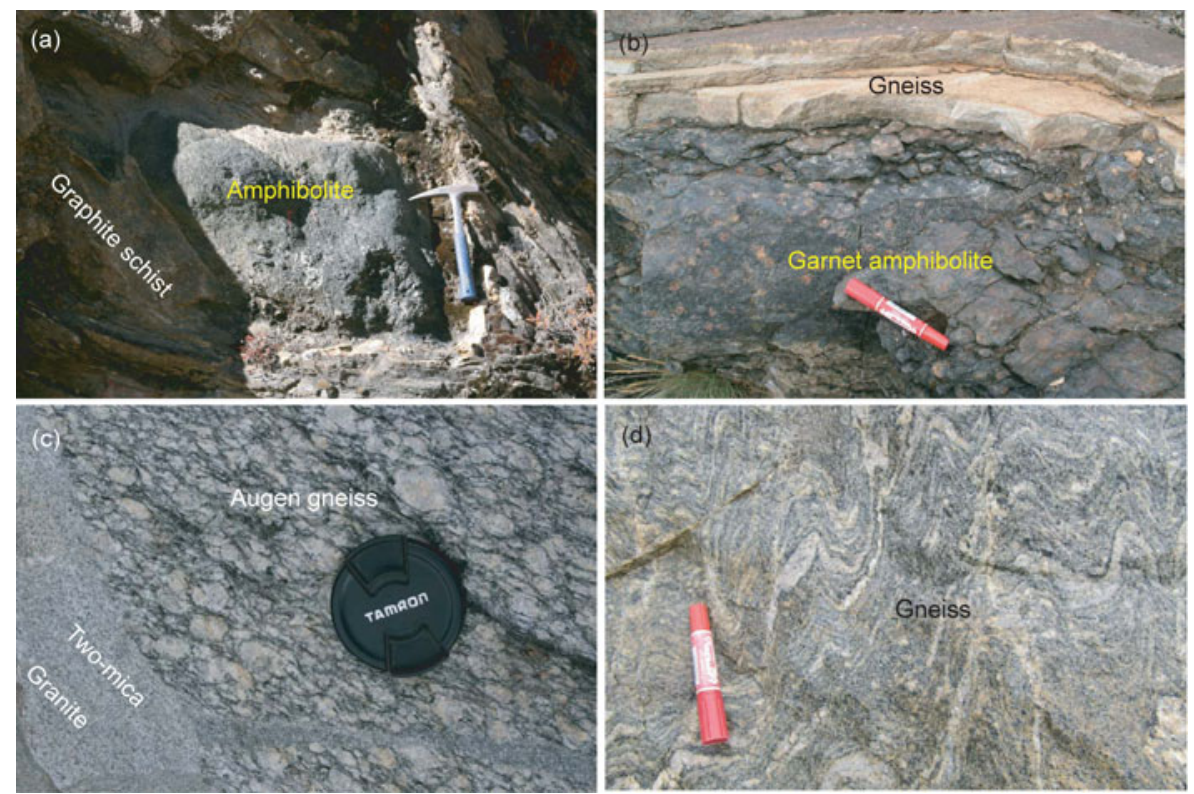

Figure 2 Field photographs showing the occurrence of high-grade metamorphic rocks in the Yardoi gneiss dome. (a) Amphibolite as lentoid within the intensively deformed garnet graphite schist; (b) garnet amphibolite occurring as relatively thick layers sub-parallel to the foliation of the granitic gneiss; (c) augen gneiss intruded by two-mica granite; (d) intensively folded granitic gneiss. 
2(c),(d)). Field observations and available ages and geochemical data show that there are three types of granites in the YGD: (1) two-mica granite formed at 42.6 $\pm 1.1 \mathrm{Ma}$ [17] with high $\mathrm{Sr} / \mathrm{Y}$ and $\mathrm{Na} / \mathrm{K}$ ratios, similar to those from the Dala and the Quedang pluton to the south [13,17,52]; (2) sub-parallel leucogranitic dikes (meters thick) intruded into the garnet graphite schist at 35.3 $\pm 1.1 \mathrm{Ma}$ [16]; and (3) MidMiocene porphyric granite with high $\mathrm{Sr} / \mathrm{Y}$ ratios and typical large leucogranites at 17.7-20.0 Ma and 17.1 Ma, respectively [53].

\section{Sample descriptions}

This study focused on the timing of high-grade metamorphic events in the garnet amphibolites and granitic gneisses.
There are three types of amphibolites in the YGD: Type-A, Type-B and Type-C. They show substantial differences in occurrence, mineral assemblage, microstructure, and geochemistry. Type-A amphibolites without any garnet are minor, and occur as small lenses within intensively deformed garnet graphite schists (Figure 2(a)). They consist of $\sim 85 \%$ hornblende and less than $15 \%$ plagioclase, quartz, muscovite and titanite (Figure 3(a)). Hornblendes are olivine in color and contain a large amount of inclusions of plagioclase, quartz, muscovite, and titanite, which is also present in the matrix. Type-B amphibolites experienced a high degree of partial melting, and are termed garnet-bearing amphibolitic migmatite. They occur as relatively thick layers sub-parallel to the foliation of the metapelite, granitic gneiss or marble (Figure 2(b)). The melanosomes consist of garnet, hornblende, epidote and titanite, whereas the leuco-
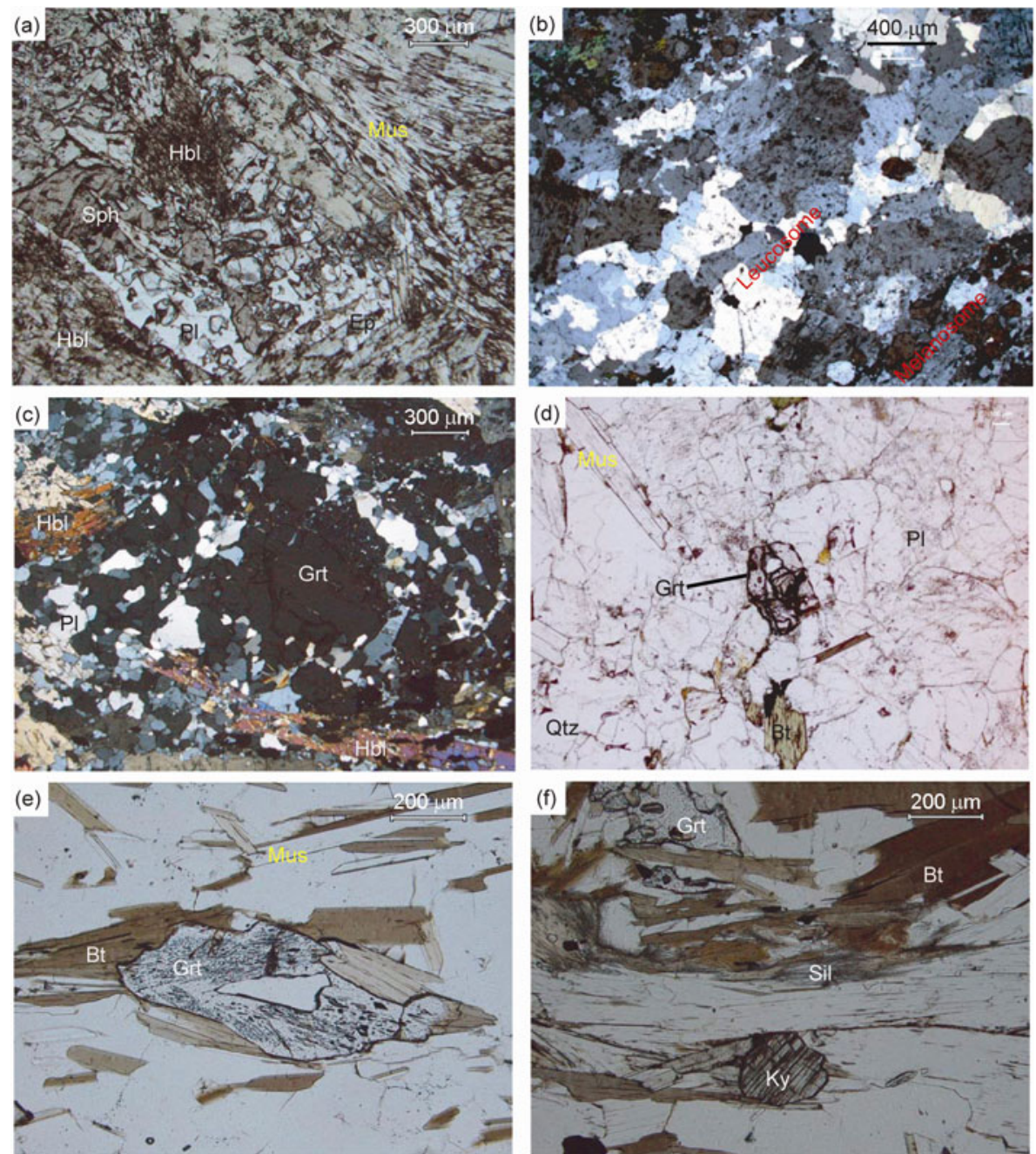

Figure 3 Photomicrographs showing the texture and mineral assemblage of high-grade metamorphic rocks from the Yardoi area. (a) Lentoid-type amphibolite (Type-A) consists of hornblende, plagioclase, quartz, muscovite and titanite; (b) migmatitic garnet amphibolite (Type-B), the leucosome consists of quartz, plagioclase and K-feldspar, whereas the melanosome comprises garnet, hornblende, epidote and titanite; (c) garnet amphibolite (Type-C) consists of hornblende, plagioclase, garnet, quartz, biotite and muscovite. Some garnets have experienced retrograde metamorphism represented by formation of sympletic biotite + plagioclase assemblage after garnet; (d) garnet-bearing granitic gneiss consisting of quartz, plagioclase, K-feldspar, biotite, muscovite, and garnet; (e)-(f) metapelite consisting quartz, plagioclase, K-feldspar, biotite, muscovite, garnet, and minor kyanite and sillimanite. Bt, biotite; Ep, epidote; Grt, garnet; Hbl, hornblende; Ky, kyanite; Mus, muscovite; Pl, plagioclase; Qtz, quartz; Sil, sillimanite; Sph, titanite. 
somes contain elevated amounts of plagioclase, quartz, and $\mathrm{K}$-feldspar. Both domains contain accessory phases of titanite, apatite, zircon, rutile and iron-oxides (Figure 3(b)). This type of amphibolite preserves a record of partial melting at 43.5 $\pm 1.3 \mathrm{Ma}$ (SHRIMP zircon U/Pb age) [17]. Similar to Type-B, Type-C amphibolites also occur as relatively thick layers within high-grade metamorphic rocks, and consist of hornblende, plagioclase, garnet, quartz, biotite, muscovite with subordinate titanite, and minor zircon, rutile and iron-oxides (Figure 3(c)). Some of the garnets in this type of amphibolite show textures of retrograde metamorphism represented by the symplectic assemblage of biotite and plagioclase surrounding the more pristine garnet grains. A large number of garnet grains are rich in inclusions of quartz, mica and rutile, which mostly display curved or sigmoid traces. Such inclusion trails imply intense shear deformation during garnet growth. The granitic gneisses consist of quartz, plagioclase, K-feldspar, biotite, muscovite, garnet and minor ilmenite, apatite, zircon and monazite (Figure 3(d)). Most of the high-grade metapelites contain minor kyanite and sillimanite (Figure 3(f)), and are of gneissic structure. Within these metapelites, the garnets show great variations in their morphology and texture and mineral composition of inclusions. Based on the types of inclusions, these garnet grains may be subdivided into four stages of growth: stage-I garnets are large and round and rich in inclusions, stage-II garnets contain large quantities of tourmaline, stage-III garnets are clean and free of inclusions, and stage-IV garnets are elongated and contain multiple sets of oriented inclusions of ilmenite and rutile (Figure 3(e)). Such feature of stage-IV garnets suggest that this type of metapelitic garnet formed from biotite dehydration partial melting. The complex growth zonations in these garnets suggest that they resulted from multi-stages of metamorphism [54].

\section{Analytical methods}

To constrain the timing of high-grade metamorphism in the Yardoi area, we separated zircons from representative type-C garnet amphibolite T0388 and biotite granitic gneiss T0395-03 using standard heavy-liquid and magnetic techniques. Then, we handpicked them under a binocular microscope. The selected grains, together with zircon standards TEMORA and M257, were embedded in $25 \mathrm{~mm}$ epoxy discs and ground to approximately half their thickness. The internal growth structure of the zircon grains was revealed by cathodoluminescence (CL) and BSE imaging. CL images were obtained at the Beijing SHRIMP Centre, Chinese Academy of Geological Sciences (CAGS). BSE images were obtained with a JSM-5610LV scanning microscope at the Institute of Geology, CAGS.

The zircons were analyzed for $\mathrm{U}, \mathrm{Th}$, and $\mathrm{Pb}$ using the SHRIMP II at the Beijing SHRIMP Centre, CAGS. The mass resolution during analytical sessions was $25000(1 \%$ height). The intensity of the primary $\mathrm{O}_{2}$ ion beam was $5 \mathrm{nA}$. Spot sizes were $\sim 25 \mu \mathrm{m}$, and each site was rastered for $180 \mathrm{~s}$ before analysis. Data were calibrated for $U$ contents by the M257 reference zircon. Five scans through the mass stations were made for each age determination. The standard zircon was analyzed first and then after every three unknowns. A TEMORA zircon with an age of $417 \mathrm{Ma}$ was used as a standard for age calibration. Data processing was carried out using the Isoplot 3.0 program, and measured ${ }^{204} \mathrm{~Pb}$ was applied for the common lead correction. The analytical data are listed in Table 1, and graphically presented in concordia diagrams with $1 \sigma$ error. The ages are weighted means with $2 \sigma$ errors calculated using Isoplot at $95 \%$ confidence levels.

\section{Data and results}

\subsection{Sample T0388}

Sample T0388 belongs to type-C amphibolite, and consists of hornblende, plagioclase, garnet, quartz, biotite, muscovite, and minor titanite, rutile, apatite, zircon and oxides. The zircon grains are euhedral to subhedral, round to long prismatic, 50-150 $\mu \mathrm{m}$ long, with aspect ratios commonly of 2. Most of the zircon grains from this sample are gray and homogeneous, and a few of them have grayish (Figure 4(b)) or white cores (Figure 4(c)), and some have very thin grayish rims (Figure 4(a),(d)). Thus, we focused U/Pb analyses on these different overgrowth zonings. $\mathrm{U}(\sim 1504 \mathrm{ppm})$ and Th $(8 \mathrm{ppm})$ concentrations in the white core are higher than those in the homogenous grayish overgrowth, which range from 16 to $301 \mathrm{ppm}$, and from 0 to $2 \mathrm{ppm}$, respectively. Th/U ratios in the homogenous domain are less than 0.05 , indicating that they are metamorphic. The grayish domains yield ${ }^{206} \mathrm{~Pb} /{ }^{238} \mathrm{U}$ ages from $42.8 \pm 1.5$ to $49.6 \pm 2.3 \mathrm{Ma}$ (Figure 4(e)) with a cluster around $45 \mathrm{Ma}$ (dotted line A) in the $\mathrm{Pb} / \mathrm{U}$ concordia diagram due to various degrees of $\mathrm{Pb}$ loss induced by metamorphism. The mean age of 5 spots is 45.0 $1.0 \mathrm{Ma}$ (MSWD, 1.6). We interpret this age as the timing of metamorphism of the garnet amphibolite in the Yardoi area. A few spots with ages of $\sim 35 \mathrm{Ma}$ (dotted line B) and of $\sim 16 \mathrm{Ma}$ (dotted line $\mathrm{C}$ ) are similar to the crystallization age of the $\sim 35.3$ Ma leucogranite [16] and the MidMiocene porphyric granite $(19.0 \pm 1.2 \mathrm{Ma})$ [54] . This indicates that the garnet amphibolite was affected by the tectonothermal events related to the formation of post-Eocene granites after the major high-grade metamorphism at a relatively deeper crustal level.

\subsection{Sample T0395-03}

Sample T0395-03 is a representative sample of the garnetbearing biotite granitic gneiss that consists of quartz, plagioclase, K-feldspar, biotite, muscovite, and garnet. There are two groups of zircons in this sample. Most of the zircon grains in group-I are euhedral to subhedral (Figure 5(a)-(c)), 
Table 1 U-Pb isotopic data for garnet amphibolite T0388 and garnet biotite granitic gneiss T0395-03 from the Yardoi gneiss dome ${ }^{\text {a) }}$

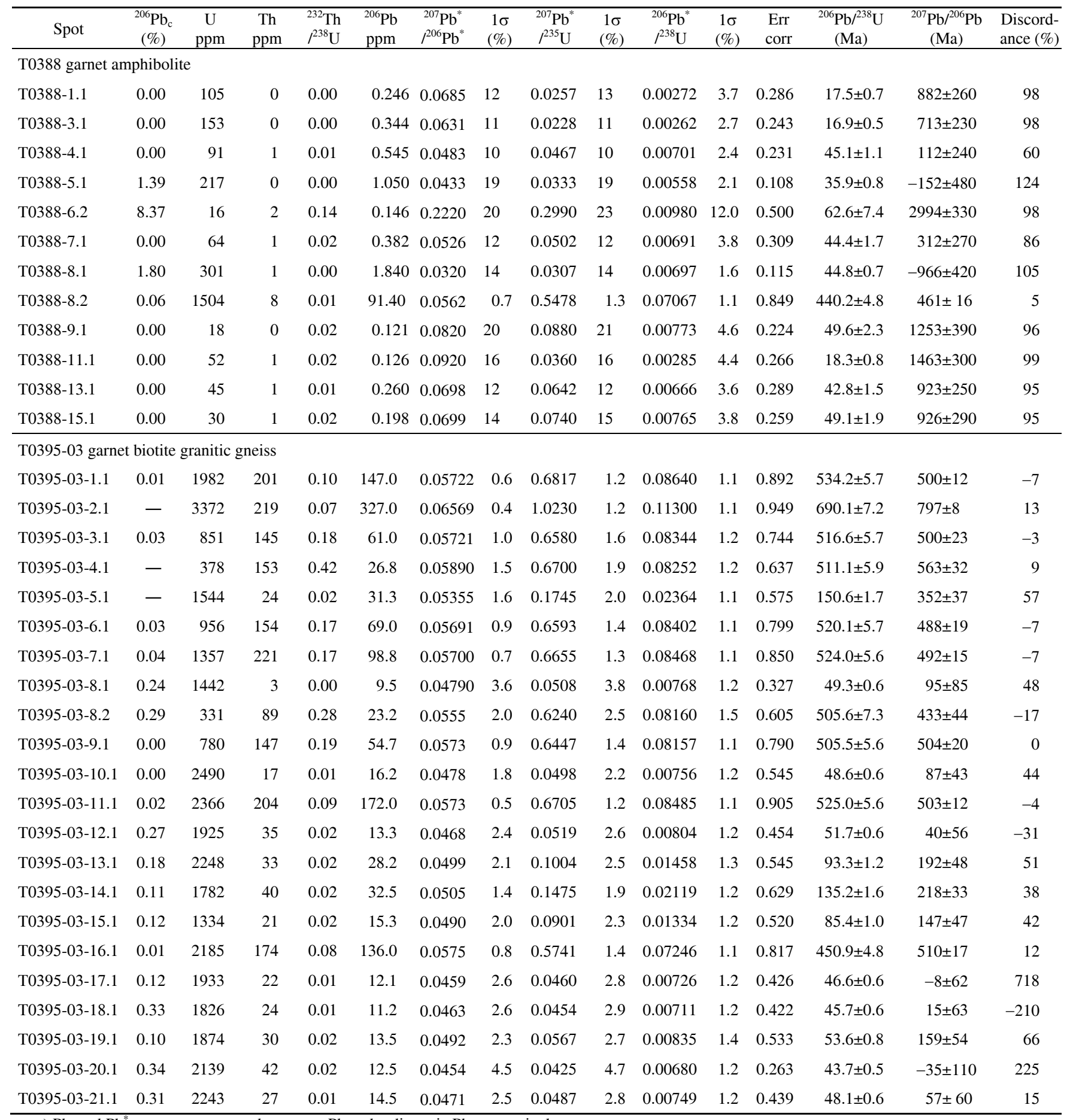

a) $\mathrm{Pb}_{\mathrm{c}}$ and $\mathrm{Pb}^{*}$ represent measured common $\mathrm{Pb}$ and radiogenic $\mathrm{Pb}$, respectively.

long prismatic, 100-200 $\mu \mathrm{m}$ long, with aspect ratios commonly of 2 and up to 3 . These zircons show a similar coremantle-rim texture, and the cores commonly are white and contain inclusions surrounded by clean mantle with typical oscillatory growth zonation indicative of magmatic origin. They are surrounded by thin dark grey rims about $30 \mu \mathrm{m}$ thick (Figure 5(a),(c)). U and Th concentrations in these os- cillatory growth zonation (mantle domain) range from 331 to $3372 \mathrm{ppm}$, and from 89 to $221 \mathrm{ppm}$, respectively, which results in great variations in $\mathrm{Th} / \mathrm{U}$ ratios $(0.07-0.42)$ (Table $1)$. The analyses performed on the domains with oscillatory growth zonation yield ${ }^{206} \mathrm{~Pb} /{ }^{238} \mathrm{U}$ ages from $450.9 \pm 4.8$ to 690.1 \pm 7.2 Ma (Figure 6a). The spot with an age of $450.9 \mathrm{Ma}$ is from a domain straddle across both the oscillatory growth 

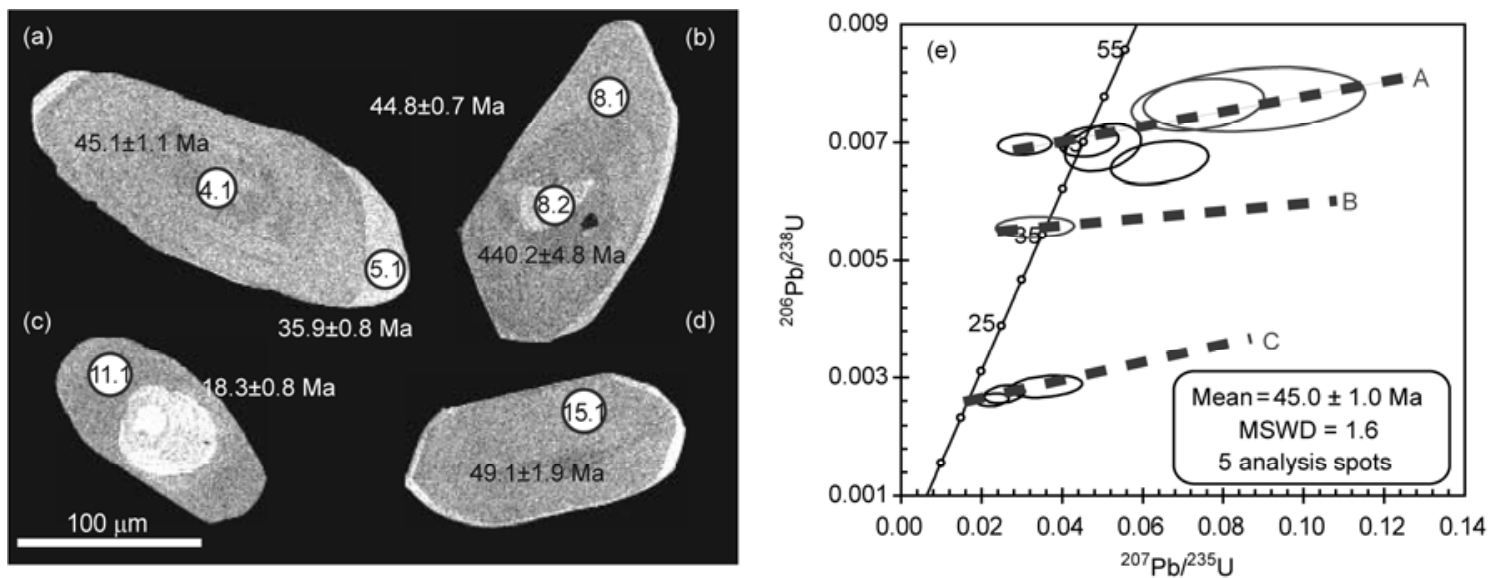

Figure 4 Cathodoluminescence (CL) images ((a)-(d)) showing the texture, spot, and respective age of SHRIMP zircon U/Pb dating and U/Pb concordia diagrams (e) for the garnet amphibolite sample T0388.
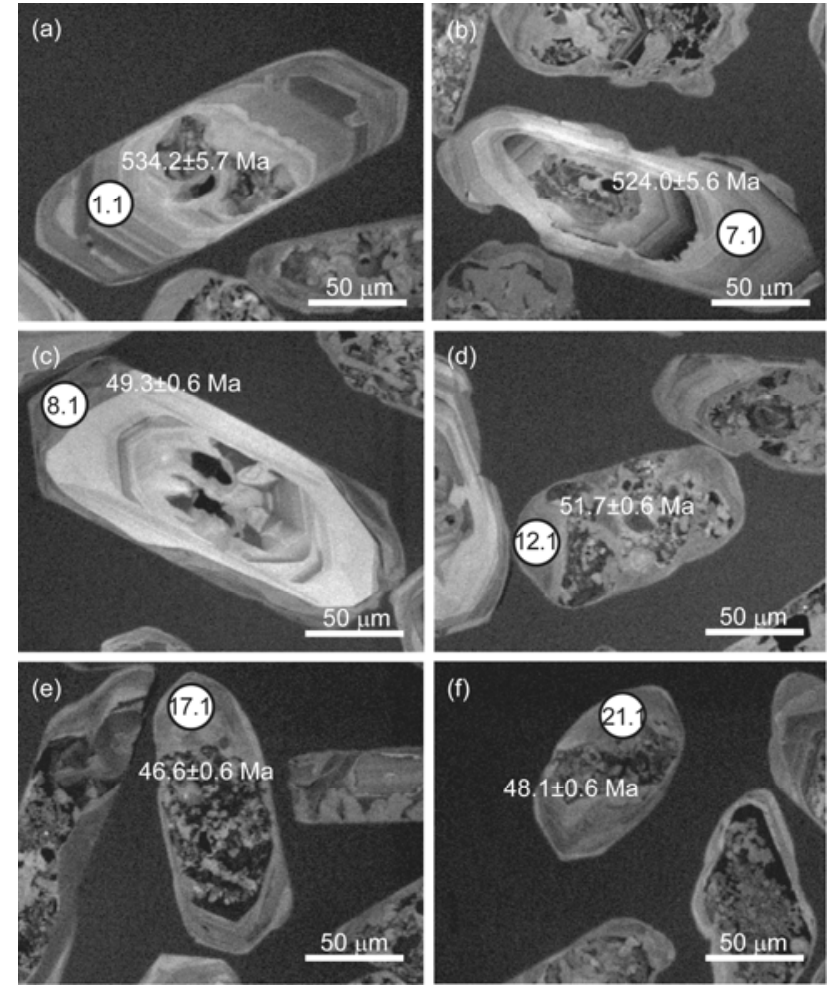

Figure 5 Cathodoluminescence (CL) images showing the texture, spot and respective age of SHRIMP zircon $\mathrm{U} / \mathrm{Pb}$ dating from garnet biotite granitic gneiss sample T0395-03.

zone and the thin latest growth zone, whereas the spot with an age of $690.1 \mathrm{Ma}$ is across both the core and the oscillatory growth zone. Both spots yield mixing ages. The other spots yield similar ${ }^{206} \mathrm{~Pb} /{ }^{238} \mathrm{U}$ ages ranging from $505.5 \pm 5.6$ to $534.2 \pm 5.7 \mathrm{Ma}$ (Table 1) with a cluster around $518.4 \mathrm{Ma}$ in a $\mathrm{Pb} / \mathrm{U}$ concordia diagram (Figure 6(b)). The mean age of 8 spots is $518.4 \pm 8.3 \mathrm{Ma}$ (MSWD, 2.9), representing the formation age of their protolith. The group-II zircon grains are subhedral to xenomorphic (Figure 5(d)-(f)), long pris- matic, 50-150 $\mu \mathrm{m}$ long, and have very high U concentrations. Because of radioactive decay of $U$, a large portion of zircon crystals experienced intensive destruction and recrystallization. On both CL and BSE images, the cores of these zircons show sponge-like textures and contain a number of inclusions. The textures are similar to those from leucogranites in the Himalaya orogenic belt, which may be related to partial melting. However, the rims of these zircon grains are clean and homogeneous. These domains were selected to perform SHRIMP U/Pb analysis. U and Th concentrations in the rims range from 1334 to $2490 \mathrm{ppm}$, and from 3 to $42 \mathrm{ppm}$, respectively. Th/U ratios are low $(<0.02$, Table 1), indicating that they are metamorphic in origin. Eight analyses yield relatively large variations in ${ }^{206} \mathrm{~Pb} /{ }^{238} \mathrm{U}$ ages ranging from $43.7 \pm 0.5$ to $53.6 \pm 0.8 \mathrm{Ma}$. Among the 8 spots, 5 spots are relatively concentrated and cluster around 47.6 $\mathrm{Ma}$ in a $\mathrm{Pb} / \mathrm{U}$ concordia diagram (Figure 6(c)), which yield a mean age of $47.6 \pm 1.8 \mathrm{Ma}(\mathrm{MSWD}, 6.6)$. We interpret this age as the timing of high-grade metamorphism of the biotite granitic gneiss.

\section{Discussion}

\subsection{High-grade metamorphism in the Himalaya Orogenic Belt}

Available data indicate that high-grade metamorphic rocks and Cenozoic granites in the YGD have preserved critical records of the style and nature of deformation, high-grade metamorphism and anatexis at middle to lower crustal levels [13,16-20,51,52]. According to their occurrences (Figure 2(a),(b)), mineral assemblage and microstructures (Figure 3), we recognized three types of amphibolites in the Yardoi area. Type-A amphibolites without any garnet occur as small lens within intensively deformed garnet graphite schist (Figures 2(a) and 3(a)). Because of an extremely low content of zircon grains, we were not able to separate enough zircons to constrain the timing of metamorphism 


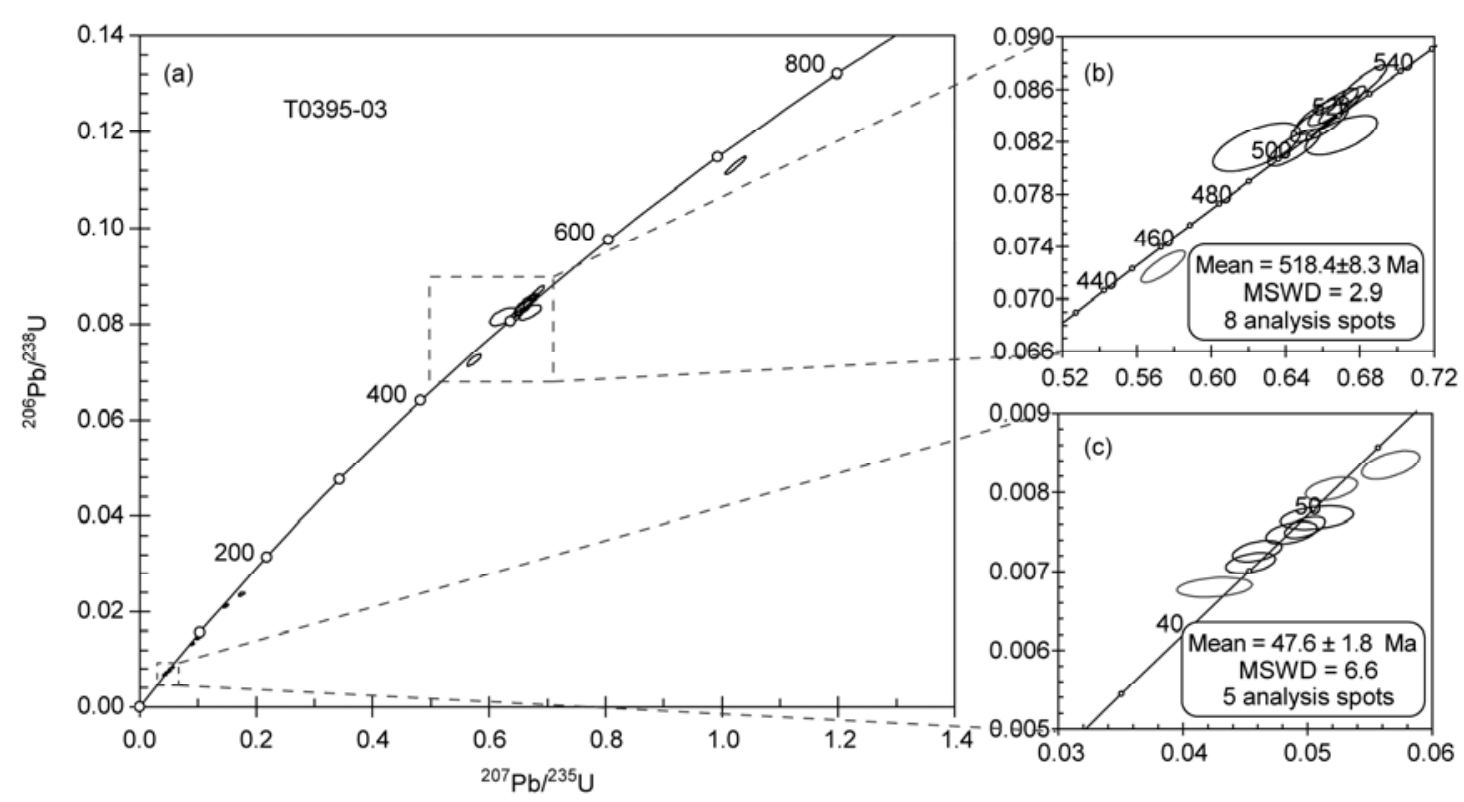

Figure 6 (a) $\mathrm{U} / \mathrm{Pb}$ concordia diagrams for the garnet biotite granitic gneiss T0395-03. Two age populations cluster at 518.4 \pm 8.3 Ma with MSWD of 2.9 as shown in (b), and a younger population at 47.6 \pm 1.8 Ma with a relatively large MSWD of 6.6 (c).

leading to the formation of this type of amphibolites. However, they are characterized by relatively radiogenic $\mathrm{Nd}$ $\left(\varepsilon_{\mathrm{Nd}}(\mathrm{i}),+1.6\right.$ to +1.9$)$ [17], and high $\mathrm{MgO}$ and $\mathrm{FeO}$ [54], suggesting that Type-A amphibolites were derived from young mafic crustal materials that intruded into the pelitic schist. Type-B migmatitic garnet amphibolites occur as relatively thick layers sub- parallel to the foliation of the metapelite, granitic gneiss or marble (Figure 2(b)). They consist of striped leucosomes of quartz, plagioclase, and K-feldspar and melanosomes of garnet, hornblende, epidote and titanite (Figure 3(b)). They have unradiogenic $\mathrm{Nd}\left(\varepsilon_{\mathrm{Nd}}(\mathrm{i}),-12.0\right.$ to -6.4) and inherited zircon cores with ages older than 440 Ma [17], which suggest that their parent rock was of ancient mafic material. Because of various degrees of partial melting, they incorporated considerable amounts of granitic melt, which lead to their elevated $\mathrm{SiO}_{2}(>68 \%)$, and lower $\mathrm{MgO}$ and $\mathrm{FeO}$ content [54]. Zircon grains from Type-B amphibolite show two kinds of microtextures [17]. A majority has a core of typical oscillatory growth zonation and a dark grey homogeneous rim; whereas, a few of them show rims with typical oscillatory growth zonation, possibly due to partial melting. The dark grey homogeneous rims yield an age of metamorphism of $43.5 \pm 1.3 \mathrm{Ma}$, similar to that from the oscillatory rim. This suggests that the timing of metamorphism and melting in Type-B amphibolites were contemporary [17]. Other than the microstructures of partial melting, the remaining features in Type- $\mathrm{C}$ amphibolites are similar to those of Type-B. CL images (Figure 4(a)-(d)) of Type-C amphibolites show that the zircons are sub-rounded and homogenous. These zircon domains show that this type of amphibolite underwent high-grade metamorphism at $45.0 \pm$ 1.0 Ma (Figure 4(e)). They has relatively unradiogenic $\mathrm{Nd}$
$\left(\varepsilon_{\mathrm{Nd}}(\mathrm{i}),-4.3\right.$ to -4.5$)$ [17], low $\mathrm{SiO}_{2}(\sim 48 \%)$, and high $\mathrm{MgO}$ and $\mathrm{FeO}(>3.5 \%)$ [54]. The data presented above indicate that high-grade metamorphism in Type-B amphibolites occurred later by $\sim 2 \mathrm{Ma}$ than that in the Type-C ones.

Some of the zircons in the granitic gneiss T0395-03 show core-mantle-rim structures, and the mantle with typical oscillatory growth zonation (Figure $5(\mathrm{a})-(\mathrm{c})$ ) yield the timing of magmatic crystallization at 518.4 \pm 8.3 Ma (Figure 6(b)). This is similar to that of parent rocks of many Himalayan granitic gneisses $[5,40,47]$, indicating that formation of these rocks was related to an Andean-type event along the northern Indian continental margin during the Paleozoic time [48,55-57]. The other zircon grains experienced intensive destruction and recrystallization due to radioactive decay of $U$, and show cores with the sponge-like texture and clean grey rims (Figure 5(d)-(f)). This texture is similar to that of many leucogranites in the Himalayan orogen, which suggests that the metamorphism could be accompanied by anatexis. However, the granitic gneiss experienced highgrade metamorphism at 47.6 $\pm 1.8 \mathrm{Ma}$ (Figure 6(c)), which is consistent with similar metamorphic ages of 47-37 $\mathrm{Ma}$ in other gneisses and garnet-bearing mica schists [54].

To estimate P-T conditions and identify key textures that could relate high-grade metamorphism to melting reactions, we made detailed observations on the mineral assemblage and microstructures of garnet amphibolite, granitic and pelitic gneiss by petrographic microscope and scanning electron microscopy (SEM). Garnets in the pelitic gneisses are complex. They commonly have multi-stage inherited cores that not only contain distinct mineral assemblage (Figure 3(d)-(f)), but also are characterized by different trace element geochemistry signatures [54]. In addition, zircon grains from 
these pelitic gneisses also contain inherited cores with ages varying from $\sim 100 \mathrm{Ma}$ to $\sim 2353 \mathrm{Ma}$, which could be correlated with multiple growth stages of garnet cores. The latest (stage-IV) garnets are pseudomorphs after kyanite and contain multiple sets of oriented inclusions of ilmenite and rutile (Figure 3(e)). Such a texture and mineral assemblage likely formed by the biotite dehydration reaction (1) under granulite facies metamorphic conditions [14,54]:

Biotite + Plagioclase + Aluminosilicate + Quartz $\rightarrow$

Garnet + K-feldspar + Ti-bearing phases + Melt

By using the mineral composition of stage-IV garnets, peak metamorphic $\mathrm{P}$ and $\mathrm{T}$ conditions were estimated to $0.8-1.0 \mathrm{GPa}$ and $624-648^{\circ} \mathrm{C}$ [54], respectively. Thermal events such as the intrusion of the $\sim 43-44$ two-mica granites and later leucogranites could have induced chemical re-equilibration of garnets, and great lower estimated $\mathrm{T}$ conditions. In contrast, after careful evaluation of the chemical zonations in the garnets, hornblendes, and plagioclases in Type- $\mathrm{C}$ garnet amphibolites, the mineral assemblage that possibly still retain local equilibrium yield near peak metamorphic $\mathrm{P}$ and $\mathrm{T}$ conditions at 1.0 to $1.1 \mathrm{GPa}$ and 872 to $892^{\circ} \mathrm{C}$, respectively [54], which is consistent with granulite facies conditions inferred from reaction (1) in pelitic gneisses.

Results from geochronology and metamorphic condition estimates as presented above indicate that different types of amphibolites and gneisses within the YGD experienced granulite facies metamorphism at 45-47 Ma, and contemporaneous metamorphism and partial melting at 43.5 $\pm 1.3 \mathrm{Ma}$ [17]. Granulite facies metamorphism in the Yardoi area occurred at a time similar to that of eclogite facies metamorphism (46.4 $\pm 0.1 \mathrm{Ma}$, zircon U/Pb data) [23] and of high-grade metamorphism of wall-rocks [22] in the Kaghan area of the High Himalaya. Interestingly, as compared with the timing of ultra-high pressure metamorphism (UHP) eclogites in the Ladakh area of the Tethyan Himalaya, our result is similar to the Sm-Nd isochron age of amphibolite facies retrograde metamorphism, but slightly younger than the Lu-Hf and Sm-Nd age of peak eclogite facies metamorphism [21]. These data suggest that high- grade metamorphic rocks in the NHGD may represent the front of the subducted Indian continental lithosphere, and metamorphic histories preserved in different localities are clearly different. In summary, these data have demonstrated that UHP metamorphism in the Tethyan Himalaya occurred at $55 \mathrm{Ma}$, high amphibolite facies to granulite facies metamorphism at 45-47 Ma, and partial melting under thickened crustal conditions at $43.5 \pm 1.3 \mathrm{Ma}$, which leads to the formation of high $\mathrm{Sr} / \mathrm{Y}$ two-mica granites [17].

\subsection{Relationship between metamorphism and partial melting}

The Himalayan orogen, a type example of active collisional belts and similar to other collisional orogenic belts, such as
Sulu UHP metamorphic terrane, have experienced not only ultra-high pressure metamorphism [21-23,58], but also retrograde metamorphism and decompressional partial melting during rapid exhumation. Results from experimental petrology [59,60] and theoretical calculations [61] have demonstrated that at UHP conditions during deep subduction or at early stages of rapid exhumation, fertile components in large-scale orogenic belts could undergo partial melting and produce granitic melts represented by polyphase inclusions in UHP minerals [62-64], granitic veins or plutons [65-68]. The Yardoi area experienced at least three stages of partial melting ( 43-44 Ma, 35 Ma and $\sim 17-20 \mathrm{Ma}$ ) and two phases of high-grade metamorphism ( 45-47 Ma and $\sim 43$ $\mathrm{Ma})$. In the Himalayan orogenic belt, all the data indicate that (1) partial melting at thickened crustal conditions and during rapid exhumation occurred at $\sim 35-44 \mathrm{Ma}$ and $\sim 10-27 \mathrm{Ma}$ in the NHGD [13,16,17,24], 32-37 Ma and $\sim 10-24 \mathrm{Ma}$ in the HHCS [15,27-29], respectively; and (2) pre-30 Ma two-mica granites and leucogranites were derived from partial melting of a source consisting of dominantly garnet amphibolite mixed with subordinate metapelite [16-20], whereas leucogranites younger than $27 \mathrm{Ma}$ resulted from decompressional mica dehydration melting of metapelite during rapid exhumation [25-29,32-37]. Compared with the Himalayan orogenic belt, the Sulu UHP belt lacks a record of anatectic events at thickened crustal conditions. Numerous data have demonstrated that parent rocks of the Sulu belt have experienced UHP eclogite facies metamorphism at 230-245 Ma [67,69,70], granulite facies [67] or amphibolite facies [71] retrograde metamorphism and decompressional partial melting at 210-215 Ma [66-68]. All the results mentioned above indicate that while there are substantial differences in the timing of and mechanisms for partial melting in different areas along the Himalayan belt, similar to the Sulu UHP belt, the subducted Indian continental slab underwent decompressional melting during its rapid exhumation. Data presented in this paper reveal that the Himalayan orogenic belt experienced at least high amphibolite facies metamorphism and partial melting, which indicates fertile components in subducted crustal materials could melt and generate granitic melt with relatively high $\mathrm{Na} / \mathrm{K}$ and $\mathrm{Sr} / \mathrm{Y}$ ratios, significantly different from those formed by decompressional melting during rapid exhumation. Whether there is a similar record in the Sulu UHP metamorphic terrane is an important issue for future research. Additionally, Harold et al. [72] demonstrated that there is a time interval of about 2-4 Ma between granulite facies metamorphism and partial melting in the Fiordland granulite, New Zealand. In the Yardoi area, Type-C garnet amphibolite and granitic gneiss underwent high-grade metamorphism at 45-47 Ma, 2-4 Ma earlier than that of partial melting, which is similar to the result of Harold et al. (2010). Whether the $2-4$ Ma time interval between highgrade metamorphism and partial melting at lower crustal conditions is universal and why this might be the case are 
important considerations deserving further investigation.

\subsection{Geological implications}

Determining the timing of onset of the India-Eurasia continental collision and reconstruction of the tectonic evolution of the Himalaya belt are important issues. Though numerous studies had been carried out in different areas along the Himalaya belt to constrain the timing of initiation of the India-Eurasia continental collision, consensus has not been reached with regard to this timing. It is widely considered that the India-Eurasia continental collision occurred at $\sim 50 \mathrm{Ma}$ or older and that it may have been diachronous [2,3,6-9]. However, Aitchison [11] reinterpreted the available data, and proposed that the beginning of the India-Eurasia continental collision occurred at $\sim 35 \mathrm{Ma}$, which was preceded by a Paleocene collision of the Indian continent with an intra-oceanic arc system. This model was questioned by Garzanti [73], and is not supported by new highquality paleomagnetic data from the longitude close to Lhasa [74-76]. In addition, Lippert [77] re-examined all the paleomagnetic data available (86 data points) and demonstrated that the Tethyan Himalaya-Asia collision occurred at 47.0 $\pm 6.5 \mathrm{Ma}$. In either model, the northern margin of the Indian continent, and probably the Tethyan Himalaya, were already in collision and underwent tectonic thickening at $\sim 44 \mathrm{Ma}$ [13].

In the early stage of a collisional orogen, intensive deformation and shortening are accompanied by metamorphism and anatexis of deep crustal materials. Documenting the timing and nature of these processes is essential to provide key insights into the early evolution and physical and chemical behavior of lower crustal materials in large-scale collisional belts. In Figure 7, we summarize the metamorphic and magmatic (or melting) events that were experienced in three tectonic belts in southern Tibet, the High Himalayan Belt, the North Himalayan Gneiss Domes and the South Lhasa block. Recent studies indicate that since 80 Ma the south Lhasa block, located at the hanging wall of the collisional belt, has experienced intensive magmatism represented by the presence of the Lingzizong volcanics and the Gandese batholith at 44-65 Ma [78,79], and two episodes of medium-pressure metamorphism at 42-55 Ma $[79,80]$ and 27-33 Ma [80], respectively (Figure 7). In comparison in the footwall, high-grade (up to UHP) metamorphism occurred at a time span similar to those of magmatism and medium-grade metamorphism in the hanging wall rocks. However, occurrence of coesite-bearing eclogite, both in the High Himalaya and the Tethyan Himalaya, indicates that the Indian Plate had already been in collision mode at this time, and that the initial India-Eurasia collision should be older than $55 \mathrm{Ma}$. The earliest partial melting of crustal materials in the footwall occurred at 44 Ma under tectonically thickened crustal conditions, and coincided with the terminal phases of igneous activities in the hanging wall, which implies a co-genetic relationship. Melting of thickened mafic lower crustal materials generally requires an input of juvenile heat from the mantle. Processes occurring during the early stage of the India-Asia collision, including NeoTethyan slab break-off following slab roll-back [9,81-83] could have led to simultaneous melting of fertile components in the hanging wall, as well as in the footwall at 43-44 Ma, and production of magmas with distinct geochemistry.

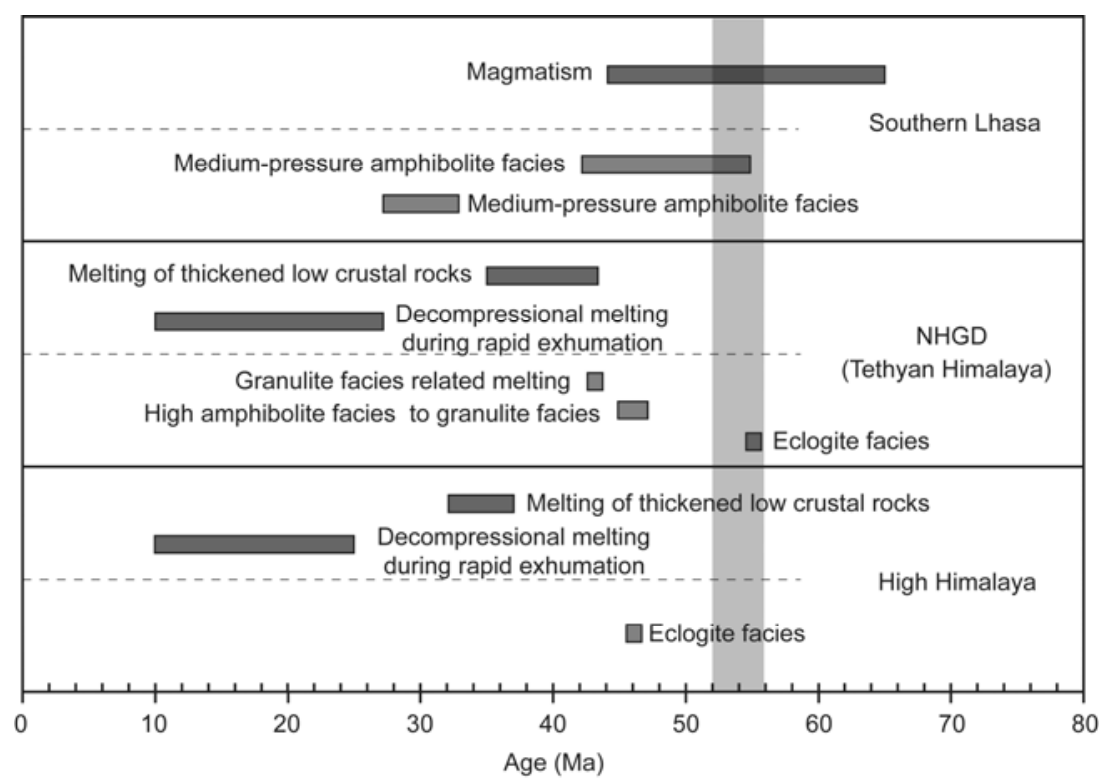

Figure 7 Diagram summarizing the magmatic (anatectic) and metamorphic events since 80 Ma both in the hanging wall (southern Lhasa block) and in the footwall (Tethyan Himalaya and High Himalaya) of the India-Eurasia collisional belt. Data sources are from [13,15-17,21-24,27-29,54,78-80]. 
We thank the editors for handling this manuscript carefully and two anonymous reviews for their constructive comments which greatly improved the manuscript. This work was supported by the National Natural Science Foundation of China (41073024 and 40921001), the National Basic Research Program of China (2011CB403102), and the Outlay Research Fund of Institute of Geology (J1004).

1 Burg J P, Guiraud M, Chen G M, et al. Himalayan metamorphism and deformations in the North Himalayan Belt (southern Tibet, China). Earth Planet Sci Lett, 1984, 69: 391-400

2 Hodges K V. Tectonics of the Himalaya and southern Tibet from two perspectives. Geol Soc Amer Bull, 2000, 112: 324-350

3 Yin A, Harrison T M. Geologic evolution of the Himalayan-Tibetan orogen. Annu Rev Earth Planet Sci, 2000, 28: 211-280

4 Beaumont C, Jamieson R A, Nguyen M H, et al. Himalayan tectonics explained by extrusion of a low-viscosity crustal channel coupled to focused surface denudation. Nature, 2001, 414: 738-742

5 Xu Z Q, Yang J S, Liang F H, et al. Pan-African and Early Paleozoic orogenic events in the Himalaya terran: Inference from SHRIMP U-Pb zircon ages (in Chinese). Acta Petrol Sin, 2005, 21: 1-12

6 Rowley D B. Age of initiation of collision between India and Asia: A review of stratigraphic data. Earth Planet Sci Lett, 1996, 145: 1-13

7 Ding L, Kapp P, Zhong D, et al. Cenozoic volcanism in Tibet: Evidence for a transition from oceanic to continental subduction. J Petrol, 2003, 44: 1833-1865

8 Zhu B, Kidd W S F, Rowley D B, et al. Age of initiation of the India-Asia collision in the east-central Himalaya. J Geol, 2005, 113: 265-285

9 Mo X X, Niu Y L, Dong G C, et al. Contribution of syncollisional felsic magmatism to continental crust growth: A case study of the Paleogene Linzizong volcanic succession in southern Tibet. Chem Geol, 2008, 250: 49-67

10 Lippert P C, Van Hinsbergen D J, Dupont Nivet G, et al. Consensus on the Eocene Latitude of Lhasa and the Age of the Tethyan Himalaya-AsiaCollision? Abstract T33F-03 presented at 2010 Fall Meeting. AGU, 2010, San Francisco, Calif. 13-17

11 Aitchison J C, Ali J R, Davis A M. When and where did India and Asia collide? J Geophys Res, 2007, 112: B05423

12 Ding L, Kapp P, Wan X. Paleocene-Eocene record of ophiolite abduction and Initial India-Asia collision, south-central Tibet. Tectonics, 2005, 24: TC3001

13 Aikman A B, Harrison T M, Ding L. Evidence for early (>44 Ma) Himalayan crustal thickening, Tethyan Himalaya, southeastern Tibet. Earth Planet Sci Lett, 2008, 274: 14-23

14 Zeng L S, Liang F H, Xu Z Q, et al. Metapelites in the Himalayan orogenic belt and their protoloith (in Chinese). Acta Petrol Sin, 2008, 24: $1517-1527$

15 Yang X Y, Zhang J J, Qi G W. Structure and deformation around the Gyirong basin, northern Himalaya, and onset of the south Tibetan detachment system. Sci China Ser D-Earth Sci, 2009, 52: 1046-1058

16 Zeng L S, Liu J, Gao L E, et al. Early Oligocene crustal anatexis in the Yardoi gneiss dome, southern Tibet and geological implications. Chin Sci Bull, 2009, 54: 104-112

17 Zeng L S, Gao L E, Xie K J, et al. Mid-Eocene high Sr/Y granites in the Northern Himalayan Gneiss Domes: Melting thickend lower continental crust. Earth Planet Sci Lett, 2011, 303: 251-266

18 Gao L E, Zeng L S, Liu J, et al. Early Oligocene Na-rich peraluminous leucogranites in the Yardoi gneiss dome, southern Tibet: Formation mechanism and tectonic implications (in Chinese). Acta Petrol Sin, 2009, 25: 2289-2302

19 Gao L E, Zeng L S, Hu G Y. High Sr/Y two-mica granite from Quedang, southern Tibet, China: Formation mechanism and tectonic implications (in Chinese). Geol Bull Chin, 2010, 29: 214-226

20 Xie K J, Zeng L S, Liu J, et al. Late-Eocene Dala adakitic granite, southern Tibet and geological implication (in Chinese). Acta Petrol Sin, 2010, 26: 1016-1026

21 De Sigoyer J, Chavagnac V, Blichert T J, et al. Dating the Indian continental subduction and collisional thickening in the northwest
Himalaya: Multichronology of the Tso Morari eclogites. Geology, 2000, 28: 487-490

22 Kaneko Y, Katayama I, Yamamoto H, et al. Timing of Himalayan ultrahigh-pressure metamorphism: Sinking rate andsubduction angle of the Indian continental crust beneath Asia. J Metamorph Geol, 2003, 21: 589-599

23 Parrish R R, Gough S J, Searle M P, et al. Plate velocity exhumation of ultrahigh-pressure eclogites in the Pakistan Himalaya. Geology, 2006, 34: 989-992

24 Zhang H F, Harris N, Parrish R, et al. Causes and consequences of protracted melting of the mid-crust exposed in the North Himalayan antiform. Earth Planet Sci Lett, 2004, 228: 195-212

25 Zhang H F, Harris N, Parrish R, et al. U-Pb ages of Kude and Sajia leucogranites in Sajia dome from North Himalaya and their geological implications (in Chinese). Chin Sci Bull, 2004, 49: 2090-2094

26 Zhang H F, Harris N, Parrish R, et al. Geochemistry of north Himalayan leucogranites: Regional comparison, petrogenesis and tectonic implications (in Chinese). Earth Sci, 2005, 30: 275-288

27 Harris N, Massey J. Decompression and anatexis of Himalayan metapelites. Tectonics, 1994, 13: 1537-1546

28 Harris N, Ayres M, Massey J. Geochemistry of granitic melts produced during the incongruent melting of muscovite-implications for the extraction of Himalayan leucogranite magmas. J Geophys Res, 1995, 100: 15767-15777

29 Harrison T M, Oscar M L, Marty G, et al. New insight into the origin of two contrasting Himalayan granite belts. Geology, 1997, 25: 899902

30 Harrison T M, Grove M, Lovera O M, et al. The origin of Himalayan anatexis and inverted metamorphism: Models and constraints. J Asian Earth Sci, 1999, 17: 755-772

31 Searle M P, Szulc A G. Channel Flow and ductile extrusion of the High Himalayan slab, Kangchenjunga-Darjeeling profile, Sikkim Himalaya. J Asian Earth Sci, 2005, 25: 173-185

32 Guillot S, Le Fort P. Geochemical constraints on the bimodal origin of High Himalayan leucogranites. Lithos, 1995, 35: 221-234

33 Ayres M, Harris N, Vance D. Possible constraints on anatectic melt residence times from accessory mineral dissolution rates: An example from Himalayan leucogranites. Mineral Mag, 1997, 61: 29-36

34 Breton N L, Thompson A B. Fluid-absent (dehydration) melting of biotite in metapelites in the early stages of crustal anatexis. Contrib Mineral Petrol, 1998, 99: 226-237

35 Patiño Douce A E, Harris N. Experimental constraints on Himalayan Anatexis. J Petrol, 1998, 39: 689-710

36 Yang X S, Jin Z M, Huenges E, et al. Genesis of granulite in Himalayan lower crust: Evidences from experimental study at high temerature and high pressure. Chin Sci Bull, 2002, 47: 448-454

37 Knesel K M, Davidson J P. Insight into collisional magmatism from isotopic fingerprints of melting reactions. Science, 2002, 296: 22062208

38 Le Fort P. Manaslu leucogranite: A collision signature of the Himalaya a model for its genesis and emplacement. J Geophys Res, 1981, 86: $10545-10568$

39 Debon F, Le Fort P, Sheppard S, et al. The four plutonic belts of the Transhimalaya-Himalaya: A chemical, mineralogical, isotopic, and chronological synthesis along a Tibet-Nepal Section. J Petrol, 1986, 27: 219-250

40 Schärer U, Xu R, Allègre C. U-(Th)-Pb systematics and ages of Himalayan leucogranites, south Tibet. Earth Planet Sci Lett, 1986, 77: 35-48

41 Daniel C, Vidal P, Fernandez A, et al. Isotopic study of the Manaslu granite (Himalaya, Nepal): Inferences of the age and source of Himalayan leucogranites. Contrib Mineral Petrol, 1987, 96: 78-92

42 Le Fort P, Cuney M, Deniel C, et al. Crustal generation of the Himalayan leucogranites. Tectonophysics, 1987, 134: 39-57

43 Inger S, Harris N. Geochemical constraints on leucogranite magmatism in the Langtang Valley, Nepal Himalaya. J Petrol, 1993, 34: 345-368

44 Searle M P, Parrish R R, Hodges K V, et al. Shisha Pangma leucogranite, south Tibetan Himalaya: Field relations, geochemistry, age, origin, and emplacement. J Geol, 1997, 105: 295-317

45 Aoya M, Wallis S R, Terada K, et al. North-south extension in the 
Tibetan crust triggered by granite emplacement. Geology, 2005, 33: 853-856

46 King J, Harris N, Argles T, et al. The contribution of crustal anatexis to the tectonic evolution of Indian crust beneath southern Tibet. Geol Soc Amer Bull, 2011, 123: 218-239

47 Lee J, Hacker B R, Dinklage W S, et al. Evolution of the Kangmar dome, southern Tibet: Structural, petrologic and thermochronologic constraints. Tectonics, 2000, 19: 872-895

48 Cawood P A, Johnson M R W, Nemchin A A. Early Palaeozoic orogenesis along the Indian margin of Gondwana: Tectonic response to Gondwana assembly. Earth Planet Sci Lett, 2007, 255: 70-84

49 Quigley M C, Yu L J, Gregory C, et al. U-Pb SHRIMP zircon geochronology and $\mathrm{T}-\mathrm{t}-\mathrm{d}$ history of the Kampa Dome, southern Tibet. Tectonophysics, 2008, 446: 97-113

50 Lee J, Whitehouse M J. Onset of mid-crustal extensional flow in southern Tibet: Evidence from U/Pb zircon ages. Geology, 2007, 35: $45-48$

51 Zhang J J, Guo L, Zhang B. Structure and kimematics of the Yalashangbo dome in the northern Himalayan dome belt, China (in Chinese). Chin J Geol, 2007, 42: 16-30

52 Qi X X, Zeng L S, Meng X J, et al. Zircon SHRIMP U-Pb dating for Dala granite in the Tethyan Himalaya and its geological implication (in Chinese). Acta Petrol Sin, 2008, 24: 1501-1508

53 Zeng L S, Gao L E, Xie K J, et al. Concurrence of Mid-Miocene high $\mathrm{Sr} / \mathrm{Y}$ granite and leucogranite in the Yardoi gneiss dome, Tethyan Himalaya, Southern Tibet. Geochim Cosmochim Acta, 2011, in press

54 Gao L E. Metamorphic and anatetic events in the Yardoi Gneiss Dome, Southern Tibet. Dissertation for the Master's Degree (in Chinese). Beijing: Chinese Academy of Geological Sciences, 2010. 1-153

55 Kusky T M, Abdelsalam M, Stern R J, et al. Evolution of the east African and related orogens, and the assembly of the Gonwana. Precambrian Res, 2003, 123: 81-85

56 Zhang Z M, Wang J L, Shen K, et al. Paleozoic circum-Gondwana orogens: Petrology and geochronology of the Namche Barwa complex in the eastern Himalayan syntaxis, Tibet (in Chinese). Acta Petrol Sin, 2008, 24: 1627-1637

57 Wang X X, Zhang J J, Yang X Y, et al. Zircon SHRIMP U-Pb ages, $\mathrm{Hf}$ isotopic features and their geological significance of the Greater Himalayan Crystalline Complex augen gneiss in Gyirong area, south Tibet (in Chinese). Earth Sci Front, 2011, 18: 127-139

58 O'Brien P J, Zotov N, Law R, et al. Coesite in Himalayan eclogite and implications for models of India-Asia collision. Geology, 2001, 29: $435-438$

59 Auzanneau E, Vielzeuf D, Schmidt M W. Experimental evidence of decompression melting during exhumation of subducted continental crust. Contrib Mineral Petrol, 2006, 152: 125-148

60 Hermann J, Spandler C J. Sediment melts at sub-arc depths: An experimental study. J Petrol, 2008, 49: 717-740

61 Yang J J, Powell R. Calculated Phase Relations in the System $\mathrm{Na}_{2} \mathrm{O}-$ $\mathrm{CaO}-\mathrm{K}_{2} \mathrm{O}-\mathrm{FeO}-\mathrm{MgO}-\mathrm{Al}_{2} \mathrm{O}_{3}-\mathrm{SiO}_{2}-\mathrm{H}_{2} \mathrm{O}$ with Applications to UHP Eclogites and Whiteschists. J Petrol, 2006, 47: 2047-2071

62 Korsakov A V, Hermann J. Silicate and carbonate melt inclusions associated with diamonds in deeply subducted carbonate rocks. Earth Planet Sci Lett, 2006, 241: 104-118

63 Zeng L S, Liu F L, Liang F H, et al. Barite in omphacite-hosted K-feldspar + quartz polycrystalline aggregates from the Sulu eclogites and its implications. Chin Sci Bull, 2007, 52: 2995-3001

64 Zeng L S, Liang F H, Paul A, et al. Partial melting of deeply subducted continental crust and the formation of quartzo-feldspathic polyphase inclusions in the Sulu UHP eclogites. Chin Sci Bull, 2009, 54: 2580-2594

65 Chen J F, Xie Z, Li H M, et al. U-Pb zircon ages for a collision-related K-rich complex at Shidao in the Sulu ultrahigh pressure terrane, China. Geochem J, 2003, 37: 35-46

66 Wallis S, Tsuboi M, Suzuki K, et al. Role of partial melting in the evolution of the Sulu (eastern China) ultrahigh-pressure terrane. Geology, 2005, 33: 129-132

67 Liu F L, Robinson P T, Gerdes A, et al. Zircon U-Pb ages, REE concentrations and $\mathrm{Hf}$ isotope compositions of granitic leucosome and pegmatite from the north Sulu UHP terrane in China: Constraints on the timing and nature of partial melting. Lithos, 2010, 117: 247-268

68 Zeng L S, Gao L E, Yu J J, et al. SHRIMP zircon U/Pb dating on ultrahigh pressure rocks from Yangkou: Implications for the timing of partial melting in the Sulu UHP metamorphic belt (in Chinese). Acta Petrol Sin, 2011, 27: 1085-1094

69 Xu Z Q, Zeng L S, Liu F L, et al. Polyphase subduction and exhumation of the Sulu high-pressure-ultrahigh-pressure metamorphic terrane. Geol Soc Am Spec Paper, 2006, 403: 93-113

70 Zheng Y F. A perspective view on ultrahigh-pressure metamorphism and continental collision in the Dabie-Sulu orogenic belt. Chin Sci Bull, 2008, 53: 3081-3104

71 Liu F L, Gerdes A, Liou J G, et al. Unique coesite-bearing zircon from allanite-bearing gneisses: $\mathrm{U}-\mathrm{Pb}, \mathrm{REE}$ and $\mathrm{Lu}-\mathrm{Hf}$ properties and implications for the evolution of the Sulu UHP terrane, China. Eur J Mineral, 2009, 21: 1225-1250

72 Harold S, Andrew T, Carlos Z, et al. Timing and duration of garnet granulite metamorphism in magmatic arc crust, Fiordland, New Zealand. Chem Geol, 2010, 273: 91-110

73 Garzanti E. Comment on "When and where did India and Asia collide?" by Jonathan C A, Jason R A, and Aileen M D. J Geophys Res, 2008, 113: B04411

74 Chen J, Huang B, Sun L. New constraints to the onset of the IndiaAsia collision: Paleomagnetic reconnaissance on the Linzizong Group in the Lhasa Block, China. Tectonophysics, 2010, 489: 189-209

75 Dupont N G, Lippert P C, Van Hinsbergen D J, et al. Paleolatitude and age of the Indo-Asia collision: paleomagnetic constraints. Geophys J Int, 2010, 182: 1189-1198

76 Liebke U, Appel E, Ding L, et al. Position of the Lhasa terrane prior to India-Asia collision derived from palaeomagnetic inclinations of 53 Ma old dykes of the Linzhou Basin: Constraints on the age of collision and post-collisional shortening within the Tibetan Plateau. Geophys J Int, 2010, 182: 1199-1215

77 Lippert P C, Van Hingberger D J, Dupont-Nivet G, et al. Consensus on the Eocene latitued of Lhasa and the age of ghe Tethyan HimalayaAsia collision? Abstract T33F-03 Presented at 2010 Fall Meeting, AGU, San Francisco, Calif, 2001, 13-17 Dec

78 Guo L, Zhang H F, Harris N, et al. Paleogene crustal anatexis and metamorphism in Lhasa terrane, eastern Himalayan syntaxis: Evidence from $\mathrm{U}-\mathrm{Pb}$ zircon ages and $\mathrm{Hf}$ isotopic compositions of the Nyingchi Complex. Gondwana Res, 2011, (in press)

79 Zhu D C, Zhao Z D, Niu Y L, et al. The Lhasa Terrane: Record of a microcontinent and its histories of drift and growth. Earth Planet Sci Lett, 2011, 301: 241-255

80 Dong X. Origin and Evolution of the Lhasa Terrane, Tibetan Plateau: Constraints from the petrological and geochronological studies of the high-grade metamorphic rocks. Dissertation for the Doctoral Degree (in Chinese). Beijing: Chinese Academy of Geological Sciences, 2011. 1-123

81 Davis J H, von Blanckenburg F. Slab breakoff: A model of lithotitanite detachment and its test in the magmatism and deformation of collisional orogens. Earth Planet Sci Lett, 1995, 129: 85-102

82 Chemenda A I, Burg J P, Mattauer M. Evolutionary model of the Himalaya-Tibet system: Geopoem based on new modelling, geological and geophysical data. Earth Planet Sci Lett, 2000, 174: 397-409

83 Kohn M J, Parkinson C D. Petrologic case for Eocene slab break off during the Indo-Asian collision. Geology, 2002, 30: 591-594

Open Access This article is distributed under the terms of the Creative Commons Attribution License which permits any use, distribution, and reproduction in any medium, provided the original author(s) and source are credited. 